\title{
Composition of gas from pyrolysis of Estonian oil shale under
}

\author{
$\mathrm{N}_{2}$ and $\mathrm{CO}_{2}$
}

\author{
Sepehr Mozaffari*1, Oliver Järvik, Zachariah Steven Baird \\ Department of Energy Technology, Tallinn University of Technology, Ehitajate tee 5, 19086 Tallinn, Estonia
}

\section{Abstract}

Studying the evolution of gas during the decomposition process of oil shale provides information about the changes of gas composition and understand the mechanism of pyrolysis process. A few number of studies focused on using $\mathrm{CO}_{2}$ atmosphere to observe the effect of sweep gas on pyrolysis products. Fischer assay method was used to analyze the pyrolysis of Estonian kukersite oil shale under $\mathrm{CO}_{2}, \mathrm{CO}_{2} /$ steam, $\mathrm{N}_{2}$ and $\mathrm{N}_{2} /$ steam. The gaseous products were collected offline using a sample bag. Gas chromatography was performed to investigate the evolution of $\mathrm{C}_{1^{-}}$ $\mathrm{C}_{3}$ gases, $\mathrm{H}_{2}, \mathrm{CO}_{2}$ and $\mathrm{CO}$. Subsequently, the results from each test were analyzed and compared. Our results show that in comparison with $\mathrm{N}_{2}$, pyrolysis in $\mathrm{CO}_{2}$ increased the production of alkanes and hydrocarbon gases. Also, generation of $\mathrm{CH}_{4}$ and $\mathrm{CO}$ gases were enhanced under $\mathrm{CO}_{2}$, while composition of $\mathrm{H}_{2}$ did not significantly change in the gaseous products for both environments. For the tests in presence of steam, the results show that unlike the $\mathrm{N}_{2}$ atmosphere, $\mathrm{CO}_{2} /$ steam decreased the production of total hydrocarbons, $\mathrm{H}_{2}, \mathrm{CO}_{2}$ and $\mathrm{CO}$.

Keywords: oil shale, fischer assay, pyrolysis, steam, gas evolution, $\mathrm{CO}_{2}, \mathrm{~N}_{2}$

\footnotetext{
*Corresponding author: email sepehr.mozaffari@taltech.ee
} 


\section{Introduction}

Among the energy sources such as coal, oil shale and biomass, oil shale is considered to have great potential due to the large size of the known deposits [1]. Therefore, oil shale can be an alternative fuel to be used as an energy source. Also, oil shale utilization could keep the balance between energy production and consumption, ensure energy security and benefit countries economically [2]. As a result, production of energy from oil shale has been used by several countries to supply and meet their energy demands. [3] For instance, Estonia has been generating energy to meet their domestic needs from shale oil by producing heat, electricity and power as well as diesel fuel while only $1.1 \%$ of the world reserves exist in Estonia. [4] However, the continual use of fossil fuels causes an increase in emission of greenhouse gases into the environment, which leads to climate change [5]. Studying various aspects of the processing of oil shale would be helpful to assess and mitigate the environmental risks [6]. In light of these reasons, investigating alternative fuels has raised interest among researchers and accordingly, abundant analysis has been done on shale oil derived from pyrolysis. However, detailed data and analysis of the shale gas from pyrolysis seems to be rare. Gas yields and compositions are important parameters to learn about the potential quality of the shale gas produced. Data on shale gas can be helpful to give better understanding about the chemistry related aspects of gas and oil formation [7]. This, in fact, depends on many factors such as the final temperature, residence time, heating rate, production approach applied, oil shale characteristics, condenser and so on. Since decomposition of kerogen and conversion to oil takes place mainly at temperatures below $500^{\circ} \mathrm{C}$, studying the evolution of gas gives more information about the gas composition as well as the mechanism of the decomposition process. The analysis of oil yield was provided in the first part of study.

In this paper the compositions of $\mathrm{H}_{2}, \mathrm{CO}, \mathrm{CO}_{2}$, and $\mathrm{C}_{1}-\mathrm{C}_{3}$ hydrocarbons in the gaseous product, and also the evolution of these gases at different temperatures during the pyrolysis are reported. These results provide insights about the release of these gases and their dependency on temperature. 


\section{Experimental section}

\subsection{Fischer assay}

A kukersite oil shale sample from the Ojamaa mine located in northeast Estonia was obtained to conduct the pyrolysis experiments. A Fischer assay retort was used to carry out the pyrolysis. $50 \mathrm{~g}$ of the oil shale sample was crushed to a particle size of $500-710 \mu \mathrm{m}$. The pyrolysis test was conducted under $\mathrm{CO}_{2}, \mathrm{CO}_{2} /$ steam, $\mathrm{N}_{2}$ and $\mathrm{N}_{2} /$ steam. The pyrolysis gases were introduced into the retort at $21 \mathrm{ml} / \mathrm{min}$ and for the steam tests the gas and water flow rates were 10 and $0.1 \mathrm{ml} / \mathrm{min}$. The sweep gases were injected into the system one hour earlier before the pyrolysis began to ensure the air was totally flushed out of the retort. Then, the retort was heated up to $500{ }^{\circ} \mathrm{C}$ at 10 ${ }^{\circ} \mathrm{C} / \mathrm{min}$, to $520^{\circ} \mathrm{C}$ at $1{ }^{\circ} \mathrm{C} / \mathrm{min}$ and held at $520^{\circ} \mathrm{C}$ for 20 minutes. The total run was carried out in $90 \mathrm{~min}$. For the tests with steam, a small heater was used to convert the injected water into steam before it reached the retort.

\subsection{Gas chromatography}

A Shimadzu GC-2014 gas chromatograph with a thermal conductivity detector and a valve system was used to analyze the various gases in a single run. $\mathrm{O}_{2}, \mathrm{~N}_{2}$, and $\mathrm{CO}$, were analyzed using a $3 \mathrm{~m}$ packed column with $5 \AA$ molecular sieves (OD 1/8", ID 2 mm, 80/100 mesh) and a 9 m 25\% DC200/Shimalite packed column (60/80 mesh, OD 1/8", ID $2 \mathrm{~mm}$ ) was used to analyze the $\mathrm{CO}_{2}$. Determining the amount of the aforementioned gases was possible by calibrating. Calibration of the $\mathrm{GC}$ was done by injecting $3 \mathrm{ml}$ of gas with different compositions of $\mathrm{O}_{2}, \mathrm{~N}_{2}, \mathrm{CO}$ and $\mathrm{CO}_{2}$. The temperature for the column oven program started from $35{ }^{\circ} \mathrm{C}$ (held isothermally for 3 minutes), followed by heating until $85^{\circ} \mathrm{C}$ at $5{ }^{\circ} \mathrm{C} / \mathrm{min}$ (also held isothermally for 3 minutes), and finally a ramp up to $125^{\circ} \mathrm{C}$ at $10^{\circ} \mathrm{C} / \mathrm{min}$. The total time was $20 \mathrm{~min}$. The injector temperature was $250^{\circ} \mathrm{C}$ and the split ratio was 10:1. Also, a Gazohrom-3101 gas chromatograph with a thermal conductivity detector (GC-TCD) was used to analyze the compositions of $\mathrm{H}_{2}, \mathrm{CO}$ and $\mathrm{CH}_{4}$. Air with a flow rate of $65 \mathrm{~mL} / \mathrm{min}$ was used as the carrier gas to determine the compositions of $\mathrm{H}_{2}, \mathrm{CO}, \mathrm{CH}_{4}$. Also, a packed 
column (ID $3.5 \mathrm{~mm}$, length $2.5 \mathrm{~m}$ ), which operated at room temperature, was used for separation. The injection volume was $2 \mathrm{~mL}$ and the relative standard deviation for parallel measurements for the GCs did not exceed $10 \%$ and 5\% respectively. In Shimadzu GC-2014, Peaks for larger hydrocarbons could also be observed. Calibrations were not available for these compounds, so to determine the compositions of $\mathrm{C}_{2}$ and $\mathrm{C}_{3}$ hydrocarbons from their peak areas, the $\mathrm{CH}_{4}$ peak area from Gazohrom was used as a reference and the ratio of the thermal conductivities was used to account for the different properties of the gases. To calculate the composition of $C_{2}$ and $C_{3}$ hydrocarbon gases, it was assumed that peak areas are directly proportional to thermal conductivity of the compounds at corresponding temperature. Although this leads to a somewhat higher uncertainty, it also allowed us to obtain information on the concentrations of these compounds that would have otherwise been lost. Consequently, the gas composition values for these compounds would rather provide qualitative data with gas trends throughout the experiment.

\section{Results and discussion}

\subsection{Gas analysis}

Table 1 and 2 present the detailed analysis of gas compositions at different test temperatures and atmospheres and how they evolved during the pyrolysis as a function of temperature. The main gases analyzed were $\mathrm{H}_{2}, \mathrm{CO}, \mathrm{CO}_{2}$, and $\mathrm{C}_{1}-\mathrm{C}_{3}$ hydrocarbons.

Table 1 Gas compositions at different phases of the Fischer Assay test under $\mathrm{N}_{2}$ and $\mathrm{N}_{2} /$ steam

\begin{tabular}{|c|c|c|c|c|c|c|c|c|}
\hline & \multicolumn{4}{|c|}{$\mathbf{N}_{2}$} & \multicolumn{4}{|c|}{$\mathrm{N}_{2} /$ steam } \\
\hline Gas composition, $\%$ & $200-400^{\circ} \mathrm{C}$ & $400-500^{\circ} \mathrm{C}$ & $500-520^{\circ} \mathrm{C}$ & $520^{\circ} \mathrm{C}$ & $200-400^{\circ} \mathrm{C}$ & $400-500^{\circ} \mathrm{C}$ & $500-520^{\circ} \mathrm{C}$ & $520^{\circ} \mathrm{C}$ \\
\hline $\mathrm{CO}_{2}$ & 2.3 & 12.3 & 10.7 & 5.8 & 1.3 & 17.0 & 14.9 & 16.2 \\
\hline
\end{tabular}




\begin{tabular}{|c|c|c|c|c|c|c|c|}
\hline & 0.0 & & & \\
\hline
\end{tabular}

Table 2 Gas compositions at different phases of the Fischer Assay test under $\mathrm{CO}_{2}$ and $\mathrm{CO}_{2} /$ steam

\begin{tabular}{|c|c|c|c|c|c|c|c|c|}
\hline \multirow[b]{2}{*}{ Gas composition, \% } & \multicolumn{4}{|c|}{$\mathrm{CO}_{2}$} & \multicolumn{4}{|c|}{$\mathrm{CO}_{2} /$ steam } \\
\hline & $200-400^{\circ} \mathrm{C}$ & $400-500^{\circ} \mathrm{C}$ & $500-520^{\circ} \mathrm{C}$ & $520^{\circ} \mathrm{C}$ & $200-400^{\circ} \mathrm{C}$ & $400-500^{\circ} \mathrm{C}$ & $500-520^{\circ} \mathrm{C}$ & $520^{\circ} \mathrm{C}$ \\
\hline $\mathrm{CO}$ & 0.1 & 7.9 & 7.7 & 2.9 & 0.4 & 6.2 & 5.0 & 2.8 \\
\hline $\mathrm{H}_{2}$ & 0.0 & 1.8 & 4.7 & 3.6 & 0.0 & 1.3 & 4.6 & 4.4 \\
\hline $\mathrm{CH}_{4}$ & 0.4 & 8.2 & 16.0 & 11.9 & 0.4 & 5.5 & 18.8 & 18.1 \\
\hline $\mathrm{C}_{2} \mathrm{H}_{4}$ & 0.1 & 1.6 & 4.8 & 0.7 & 0.2 & 1.2 & 3.0 & 2.0 \\
\hline $\mathrm{C}_{2} \mathrm{H}_{6}$ & 0.1 & 5.1 & 16.3 & 2.0 & 0.1 & 3.8 & 9.5 & 5.6 \\
\hline $\mathrm{C}_{3} \mathrm{H}_{6}$ & 0.0 & 5.7 & 7.8 & 0.0 & 0.0 & 7.5 & 7.1 & 4.4 \\
\hline $\mathrm{C}_{3} \mathrm{H}_{8}$ & 0.0 & 4.0 & 11.2 & 0.5 & 0.0 & 3.4 & 7.2 & 4.1 \\
\hline Total HC gases & 0.6 & 24.6 & 56.2 & 15.1 & 0.8 & 21.5 & 45.6 & 34.2 \\
\hline Alkanes & 0.5 & 17.3 & 43.5 & 14.3 & 0.6 & 12.7 & 35.5 & 27.8 \\
\hline Alkenes & 0.1 & 7.3 & 12.7 & 0.7 & 0.2 & 8.8 & 10.1 & 6.4 \\
\hline Alkenes/Alkanes ratio & 0.2 & 0.4 & 0.3 & 0.1 & 0.4 & 0.7 & 0.3 & 0.2 \\
\hline
\end{tabular}


Campbell et al. [33] studied oil shale pyrolysis mechanisms from $25{ }^{\circ} \mathrm{C}$ to $900{ }^{\circ} \mathrm{C}$ and described oil shale pyrolysis as a simplified two-step process of kerogen to bitumen and bitumen to oil. In addition, they suggested that only small amounts of non-condensable gases are produced during the process of conversion of kerogen to bitumen; however, during the conversion of bitumen to oil, evolution of non-condensable gases takes place [8]. This also can be found in this work as seen from Table 1. Only traces of non-condensable gases were produced before $400{ }^{\circ} \mathrm{C}$ and above this temperature up to $500{ }^{\circ} \mathrm{C}$ the main evolution of oil and gas can be observed.

The detailed analysis of evolved hydrocarbon gases during the pyrolysis as a function of temperature and the presence of steam is shown in Figures 1-3. As shown in the figures, in all test environments total HC gases, alkanes and alkenes were increased by increasing the retort temperature. Moreover, these figures indicate that steam caused an increase in the concentration of hydrocarbon gases, alkanes and alkenes in the gaseous products for the nitrogen atmosphere. These results agree with several other researchers' works [9]-[11]. Nazzal [12] suggested that the presence of steam in oil shale pyrolysis could play an important role on the exit gas composition because in addition to having a high heat capacity, steam speeds up the pyrolysis process. Also, steam increases the heating value of gaseous product after condensation as a result of increase in concentrations of $\mathrm{CO}$ and $\mathrm{H}_{2}$. 


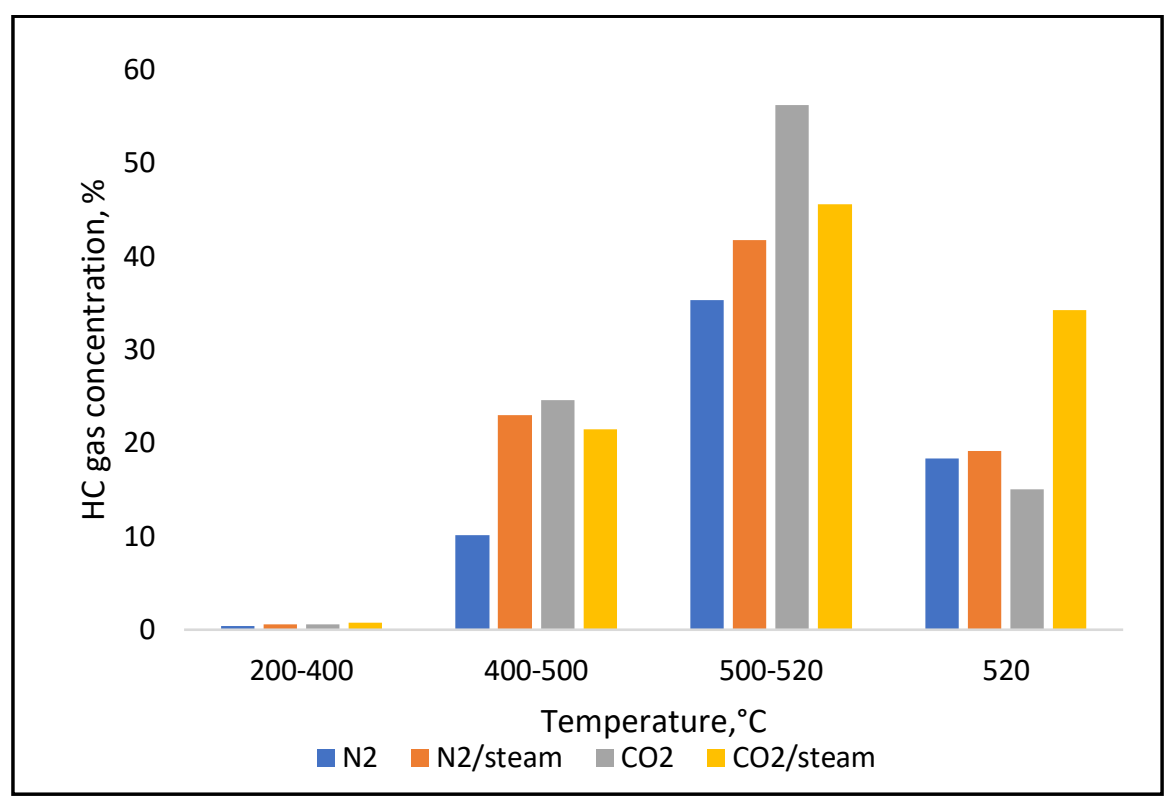

Figure 1 Relative distribution of hydrocarbon gases produced

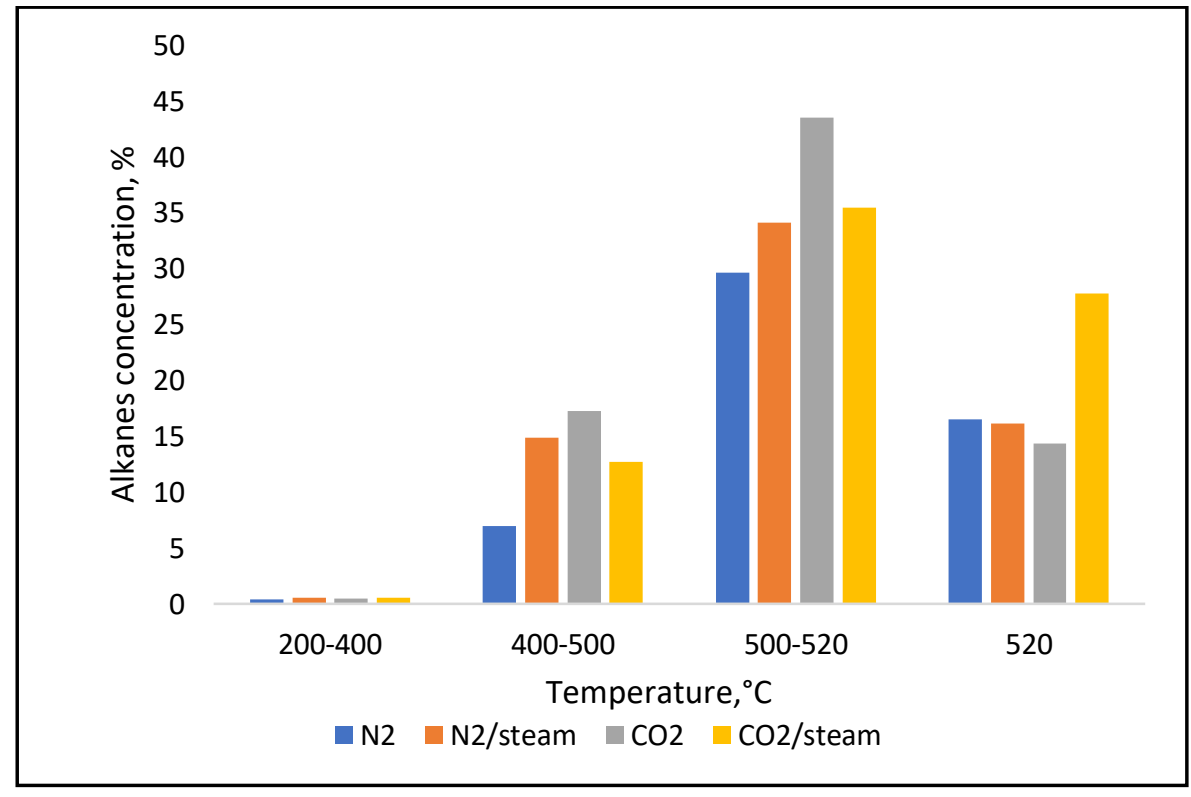

Figure 2 Evolution of alkane gases 


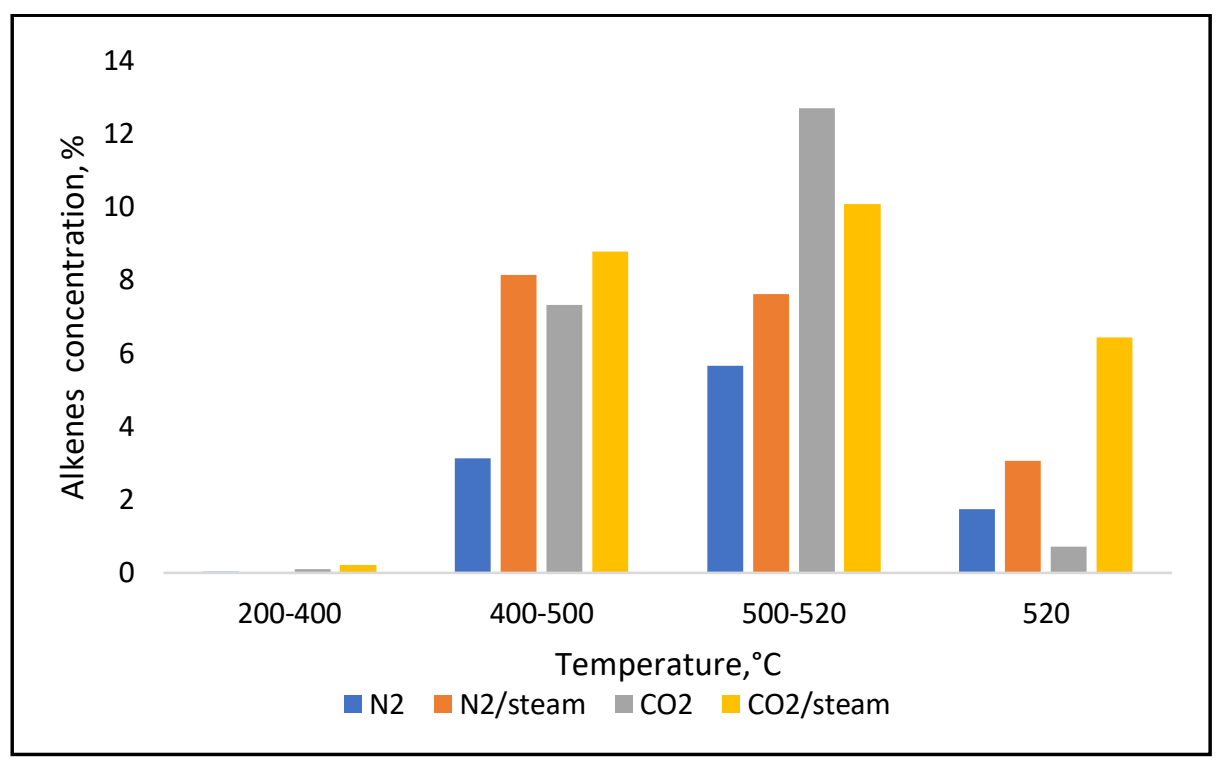

Figure 3 Evolution of alkene gases

However, looking at the graphs more closely, it seems that steam has the opposite effects when injected into $\mathrm{N}_{2}$ and $\mathrm{CO}_{2}$ environments. In an $\mathrm{N}_{2}$ atmosphere, steam enhanced the total amounts of $\mathrm{HC}$ gases, alkanes and alkenes. These results agree with Nazzal's findings where a small increase in total HC gases and alkenes and a slight difference in alkanes production was observed between 400 ${ }^{\circ} \mathrm{C}$ and $520^{\circ} \mathrm{C}$ in the nitrogen/steam environment [12]. As stated earlier, the results show a different effect for steam in a $\mathrm{CO}_{2}$ atmosphere. In $\mathrm{CO}_{2}$, steam caused a decrease in total hydrocarbon and alkane gases production; however, the presence of steam initially increased the concentration of alkene gases (up to $400{ }^{\circ} \mathrm{C}$ ), and then reduced it as evolution of oil began to occur $\left(450{ }^{\circ} \mathrm{C}\right.$ ). Subsequently, steam seemed to decrease the concentration of alkenes at higher temperatures.

Table 1 also shows the alkenes/alkanes ratios for all tests during the $\mathrm{HC}$ gases evolution. The ratio of alkenes to alkanes has been used to determine reaction mechanisms and indicates pyrolysis conditions [11], [13]. Several researchers have suggested that an increase in the alkene/alkane ratio is a result of secondary cracking reactions [9], [11], [12] and lower ratios are associated with coking reactions [1], [2]. The results for the alkene/alkane ratio show that initially the ratio increased and then decreased during pyrolysis. The highest values for the alkene/alkane ratio can be due to the occurrence of secondary gas phase reactions in the temperature range of $400{ }^{\circ} \mathrm{C}$ to $500{ }^{\circ} \mathrm{C}$ where 
oil and gas evolution largely takes place. Moreover, these ratios were mostly higher for the pyrolysis with steam. Williams and Nazzal [9] suggested that even though steam increases the oil yield by decreasing the secondary coking reactions it also increases the alkene/alkane ratio, meaning an increase in the secondary vapor phase cracking reactions.

Figure 4 exhibits the evolution of $\mathrm{CO}_{2}$ in the gas products during pyrolysis in $\mathrm{N}_{2}$ and $\mathrm{N}_{2} /$ steam. Even though studying $\mathrm{CO}_{2}$ evolution for the tests in $\mathrm{CO}_{2}$ was not possible, such measurements were made for the $\mathrm{N}_{2}$ and $\mathrm{N}_{2}$ /steam environments. It can be seen from the figure that the yield of $\mathrm{CO}_{2}$ was greatly increased under the run with steam. This could be as a result of various reactions such as the water-gas shift reaction, mineral carbonate decomposition reactions as well as steamhydrocarbon reactions. By increasing the pyrolysis temperature, decomposition of mineral carbonates and production of water increases, which leads to higher production of $\mathrm{CO}_{2}[12]$. Looking at the yield of gases throughout the pyrolysis process (up to $500{ }^{\circ} \mathrm{C}$ ) indicates that $\mathrm{CO}_{2}$ made up the largest portion of the gaseous products. This may suggest that water vapor plays a role in oxidation reactions.

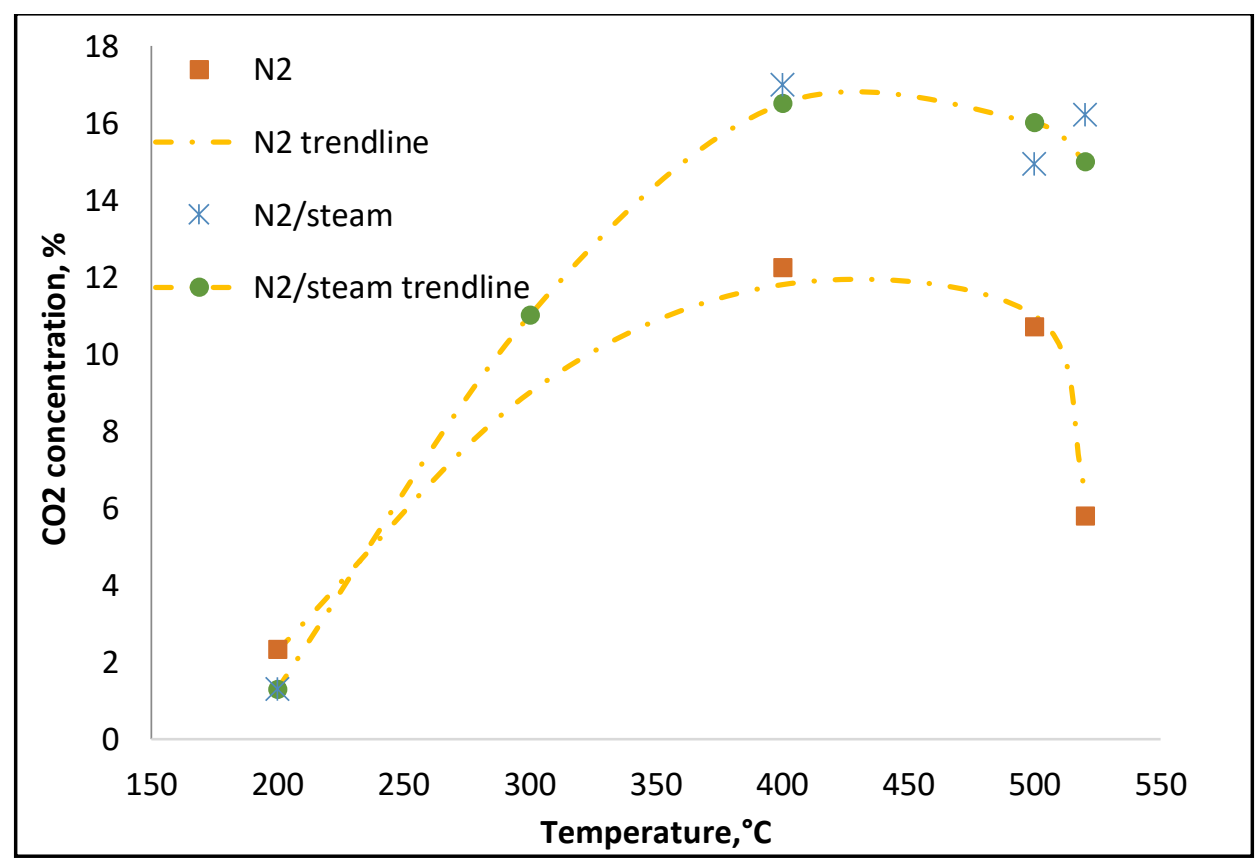

Figure $4 \mathrm{CO}_{2}$ evolution as a function of temperature 
William and Nazzal [12] related the higher gas yield in $\mathrm{N}_{2}$ /steam to the higher $\mathrm{CO}_{2}$ concentration that is produced at higher temperatures and suggested that this is coupled with a series of reactions, namely the char-steam, water gas-shift, hydrocarbon steam and mineral carbonatesteam reactions.

Figures 5-7 compare the yields of $\mathrm{CO}$ and $\mathrm{H}_{2}$ and $\mathrm{CH}_{4}$ during the decomposition of kerogen. Since the gas sampling was offline, it was not possible to find the precise peak temperature where the evolution of gas takes place. From the figures it can be perceived that the peak for carbon monoxide, hydrogen and methane evolution occurs at around $400-450{ }^{\circ} \mathrm{C}, 480-510{ }^{\circ} \mathrm{C}$ and $500{ }^{\circ} \mathrm{C}$, respectively. Huss and Burnham [14] also studied the gas evolution of different shale samples during pyrolysis in a reactor under argon over a temperature range of $25-950^{\circ} \mathrm{C}$ at the heating rate of $2{ }^{\circ} \mathrm{C} / \mathrm{min}$. Their findings show that $\mathrm{CO}, \mathrm{H}_{2}$ and $\mathrm{CH}_{4}$ evolution mostly happens at $425-435{ }^{\circ} \mathrm{C}, 465$ ${ }^{\circ} \mathrm{C}$ and $480-520{ }^{\circ} \mathrm{C}$, respectively. They associated this phenomenon with oil generation which occurred at the maximum rate at $430-435^{\circ} \mathrm{C}$.

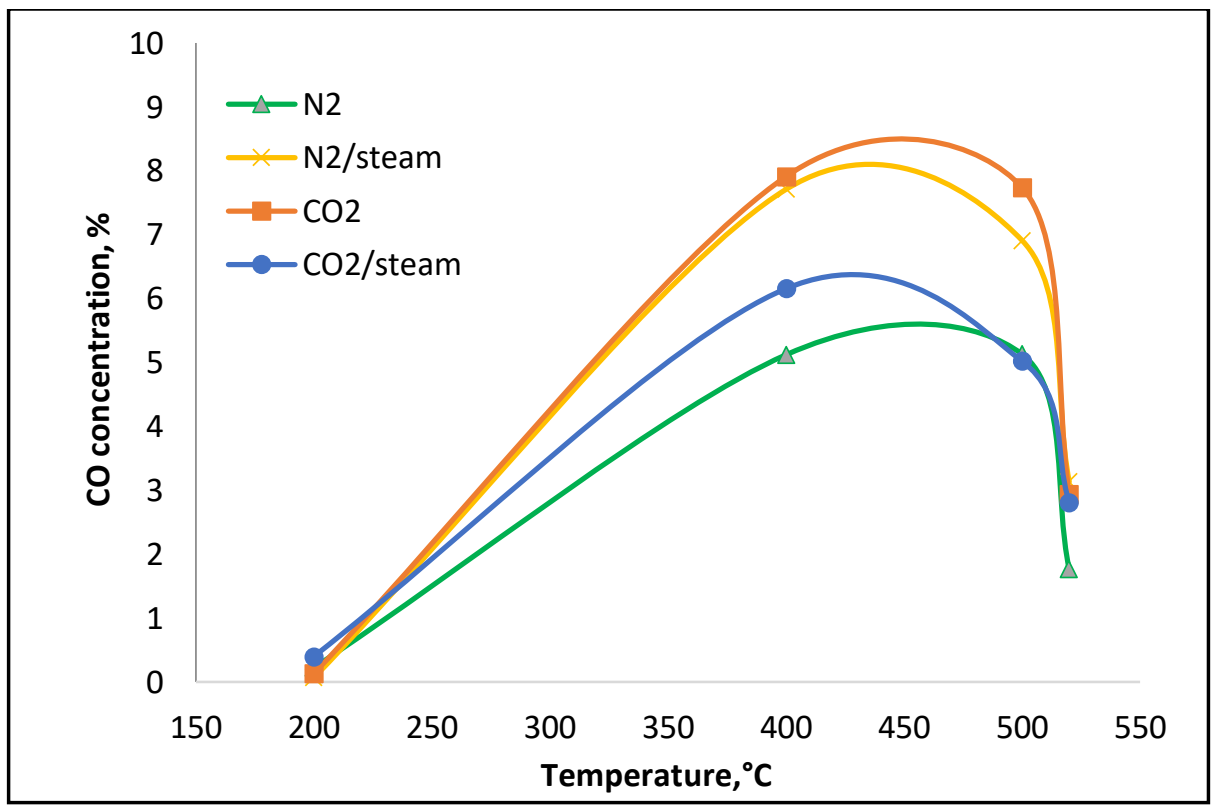

Figure 5 Evolution of $\mathrm{CO}$ during kerogen decomposition 


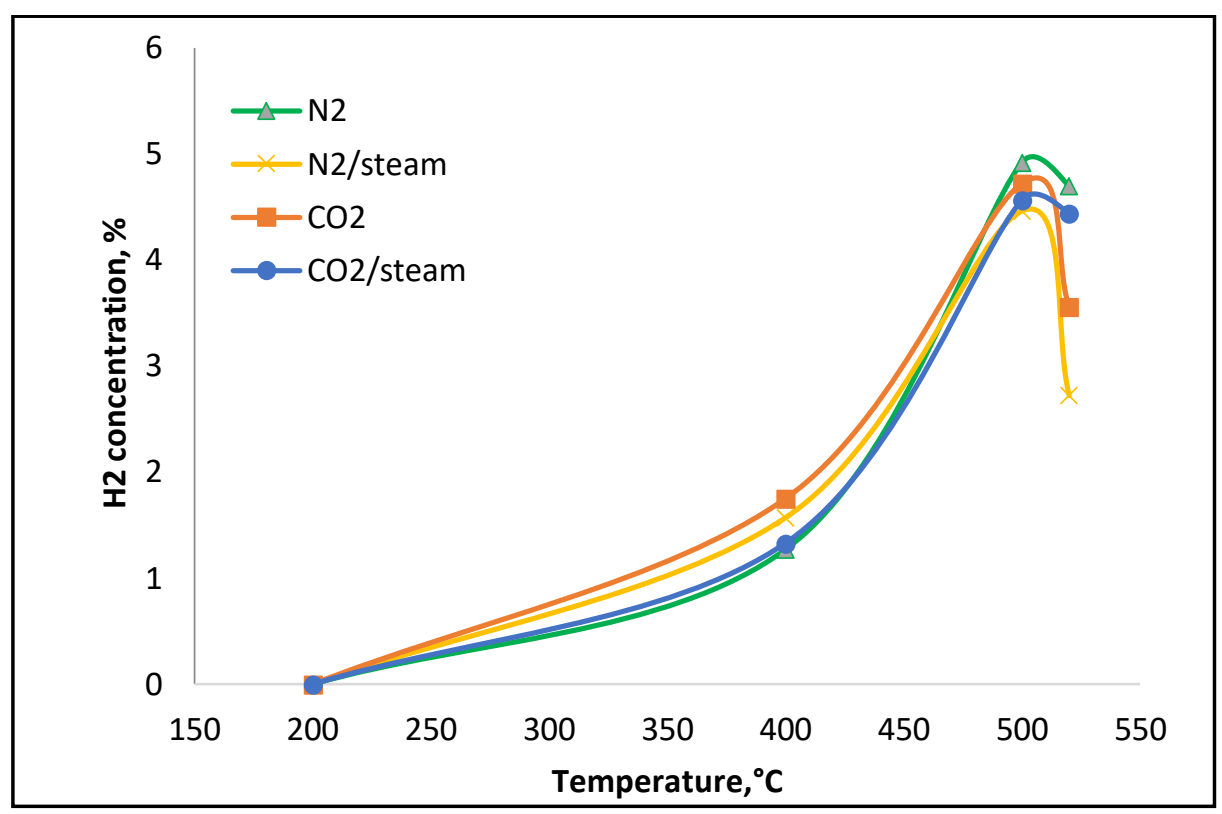

Figure 6 Evolution of $\mathrm{H}_{2}$ during kerogen decomposition

The experimental results showed that in the presence of steam CO starts to be produced at around $400{ }^{\circ} \mathrm{C}$ and has its highest content when the oil is about to be generated. It appears that the concentration of $\mathrm{CO}$ in nitrogen pyrolysis is lower than that in nitrogen/steam. That is partially because of the reactions that the produced water and injected steam initiate with the char to produce hydrogen and carbon monoxide. Also, in the water gas shift reaction, steam and CO produce hydrogen and $\mathrm{CO}_{2}$. These reactions seem to have an effect on the compositions of $\mathrm{CO}$ and $\mathrm{H}_{2}$ in the retort. In addition, at higher temperatures, the $\mathrm{CO}$ composition is reduced and hydrogen increased. Also, it appears from the results in nitrogen that using $\mathrm{CO}_{2}$ as a sweep gas significantly increased the amounts of $\mathrm{CO}$ and $\mathrm{H}_{2}$ in the gaseous products. Generally, it was observed that steam injection into a $\mathrm{CO}_{2}$ atmosphere lowered the yields of $\mathrm{H}_{2}$ and $\mathrm{CO}$ in the produced gas and increased them in the nitrogen environment. 


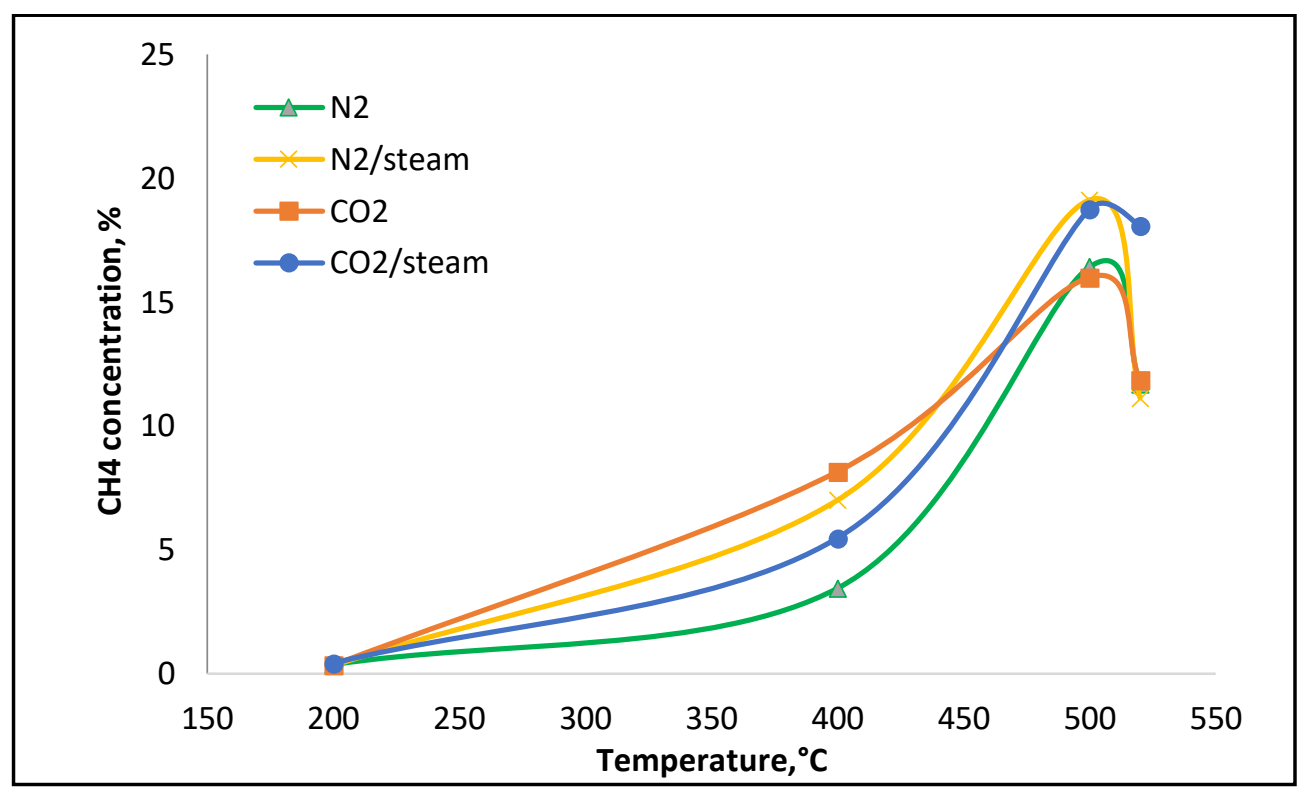

Figure 7 Evolution of $\mathrm{CH}_{4}$ during kerogen decomposition

Comparison of methane evolution in the products indicates that $\mathrm{CH}_{4}$ formation is higher in a $\mathrm{CO}_{2}$ atmosphere than in $\mathrm{N}_{2}$. It is apparent that the presence of steam yielded higher methane concentrations in $\mathrm{N}_{2}$ at all temperatures while in $\mathrm{CO}_{2}$ methane formation only increased at higher temperatures. This can be explained by the following reaction between steam and hydrocarbon gases in which oxygen and methane are formed. For this reason, the yield of methane in pyrolysis with steam is higher.

$$
2 \mathrm{HC}+\mathrm{H}_{2} \mathrm{O} \rightarrow \mathrm{O}_{2}+\mathrm{CH}_{4}
$$

It is worth noting that a sharp increase can be observed from about $400{ }^{\circ} \mathrm{C}$ onward. This is the approximate temperature when bitumen is converted to oil and shale oil generation begins. As explained before, as the temperature increased the total concentration of $\mathrm{HC}$ gases increased and consequently $\mathrm{H}_{2}$ and $\mathrm{CH}_{4}$ formation in the retort increased as well. During the last phase of the test (where the retort temperature was held at $520^{\circ} \mathrm{C}$ for 20 minutes) and due to consumption of the shale sample over time, less hydrocarbons were produced and as a result methane formation decreased. 


\section{Conclusions}

This research focused on gaseous products of the pyrolysis of Estonian kukersite oil shale under the Fischer assay method. The test was conducted in four different atmospheres; $\mathrm{CO}_{2}, \mathrm{CO}_{2} /$ steam, $\mathrm{N}_{2}$ and $\mathrm{N}_{2} /$ steam. Gas chromatography was used to measure the composition of all collected gases. The gas analysis showed that more hydrocarbon gases were produced when steam was injected in $\mathrm{N}_{2}$. Conversely, the presence of steam caused a reduction in total hydrocarbon gases and alkane gases in a $\mathrm{CO}_{2}$ atmosphere. Moreover, the results from $\mathrm{CO}_{2} /$ steam indicated that steam lowered the concentrations of $\mathrm{H}_{2}$ and $\mathrm{CO}$ compared with the $\mathrm{CO}_{2}$ atmosphere. Furthermore, the alkenes/alkanes ratio, which is used to determine reaction mechanisms, showed an initial increase followed by a decrease in the ratio. Analyzing and investigating the outcomes obtained from studying gas evolution could result in development and advancement of processes and technology to enhance the oil and gas yields.

\section{REFERENCES}

[1] W. Sha, J. Liu, X. Jiang, X. Han, and J. Tong, "Effect of heating rate on products yield and characteristics of non-condensable gases and shale oil obtained by retorting Dachengzi oil shale," Oil Shale, vol. 30, no. 1, pp. 27-47, 2013, doi: 10.3176/oil.2013.1.04.

[2] S. Wang, X. Jiang, X. Han, and J. Tong, "Effect of residence time on products yield and characteristics of shale oil and gases produced by low-temperature retorting of Dachengzi oil shale," Oil Shale, vol. 30, no. 4, pp. 501-516, 2013, doi: 10.3176/oil.2013.4.04.

[3] Z. S. Baird, P. Uusi-Kyyny, O. Järvik, V. Oja, and V. Alopaeus, "Temperature and Pressure Dependence of Density of a Shale Oil and Derived Thermodynamic Properties," Ind. Eng. Chem. Res., vol. 57, no. 14, pp. 5128-5135, 2018, doi: 10.1021/acs.iecr.7b05018.

[4] N. D. Ristic, M. R. Djokic, A. Konist, K. M. Van Geem, and G. B. Marin, "Quantitative compositional analysis of Estonian shale oil using comprehensive two dimensional gas 
chromatography," Fuel Process. Technol., vol. 167, pp. 241-249, 2017, doi:

10.1016/j.fuproc.2017.07.008.

[5] P. Mozaffari, O. Järvik, and Z. S. Baird, "Vapor Pressures of Phenolic Compounds Found in Pyrolysis Oil," J. Chem. Eng. Data, 2020, doi: 10.1021/acs.jced.0c00675.

[6] P. Mozaffari, Z. S. Baird, M. Listak, and V. Oja, "Vapor pressures of narrow gasoline fractions of oil from industrial retorting of Kukersite oil shale," Oil Shale, vol. 37, no. 4, pp. 288-303, 2020, doi: 10.3176/oil.2020.4.03.

[7] T. T. Coburn, "Eastern oil shale retorting: Gas evolution during pyrolysis of northeastern kentucky shales," Energy Sources, vol. 7, no. 2, pp. 121-150, 1983, doi: 10.1080/00908318308908080.

[8] J. H. Campbell, G. J. Koskinas, G. Gallegos, and M. Gregg, "Gas evolution during oil shale pyrolysis. 1. Nonisothermal rate measurements," Fuel, vol. 59, no. 10, pp. 718-726, 1980, doi: 10.1016/0016-2361(80)90027-7.

[9] P. T. Williams and J. M. Nazzal, "Polycyclic aromatic compounds in shale oils: Influence of process conditions," Environ. Technol. (United Kingdom), vol. 19, no. 8, pp. 775-787, 1998, doi: 10.1080/09593331908616734.

[10] S. Wang, X. Jiang, X. Han, and J. Tong, "Effect of retorting temperature on product yield and characteristics of non-condensable gases and shale oil obtained by retorting Huadian oil shales," Fuel Process. Technol., vol. 121, pp. 9-15, 2014, doi: 10.1016/j.fuproc.2014.01.005.

[11] P. T. Williams and N. Ahmad, "Influence of process conditions on the pyrolysis of Pakistani oil shales," Fuel, vol. 78, no. 6, pp. 653-662, 1999, doi: 10.1016/S0016-2361(98)00190-2.

[12] J. M. Nazzal, "Gas evolution from the pyrolysis of Jordan oil shale in a fixed-bed reactor," J. Therm. Anal. Calorim., vol. 65, no. 3, pp. 847-857, 2001, doi: 10.1023/A:1011936401407. 
[13] P. T. Williams and J. M. Nazzal, "Polycyclic aromatic compounds in oils derived from the fluidised bed pyrolysis of oil shale," J. Anal. Appl. Pyrolysis, vol. 35, no. 2, pp. 181-197, 1995, doi: 10.1016/0165-2370(95)00908-9.

[14] E. B. Huss and A. K. Burnham, "Gas evolution during pyrolysis of various Colorado oil shales," Fuel, vol. 61, no. 12, pp. 1188-1196, 1982, doi: 10.1016/0016-2361(82)90018-7. 